\title{
A NAPELEMES ÜZLETI MODELLEK FEJLŐDÉSE
}

A megújuló energiaforrások használata napjainkban világszinten növekvő tendenciát mutat, azonban számos olyan akadállyal találkozhatunk, amelyek gátolják az új technológiák és ezáltal a decentralizált energiatermelés elterjedését. A szerzők elméleti összefoglaló cikkükben a Business Model Canvas alkalmazásán keresztül áttekintik a világszinten azonosítható napelemes üzleti modelleket. Ezt követően hat tényezőt azonosítanak, amelyek mentén a modellek jól elhatárolhatóvá válnak egymástól. Végül Osterwalder és Pigneur (2010) üzletimodell-definíciója alapján bemutatják, az egyes modellek - felhasználó és harmadik fél által tulajdonolt, közösség által megosztott - értékajánlatát, valamint az értékteremtésének, nyújtásának és megragadásának módját.

\section{Kulcsszavak: Business Model Canvas, üzletimodell-innováció, megújuló energia, közösségi finanszírozás}

A növekvő keresletnek, az új piacok és technológiák megjelenésének köszönhetően a megújuló energiaforrások iparága jelentős növekedésnek indult meg világszinten az utóbbi években. (REN21, 2016). Azonban a GTM Research elörejelzései alapján, a napelemes rendszerek irányába mutatkozó kereslet növekedése globális szinten lassulni fog 2018-ban (Mond, 2017). A főbb piacokon várható visszaesés a szakpolitikai változásokhoz és szabályozási bizonytalanságokhoz köthető (Attia - Parikh, 2016).

A környezeti feltételek megváltozása az utóbbi években olyan innovatív koncepciók kialakításához vezetett a napelemek piacán, amelyek segítségével kezelhetővé válik a megnövekedett komplexitás. A megújuló energiaforrások - beleértve a napelemes rendszerek - elterjedését jelentős mértékben gátolhatják olyan pénzügyi akadályok, mint például a magas kezdeti befektetési költségek és a pénzügyi erőforrások hiánya. Ezen pénzügyi akadályok kezelésében kiemelt szerepet kap a napelemek piacán a harmadik fél által tulajdonolt, valamint a közösség által megosztott üzleti modell. Míg a harmadik fél által tulajdonolt koncepció energiavásárlási és lízingszerződéseket kínál a fogyasztók számára, addig a közösség által megosztott modell virtuális mérés alkalmazásával lehetővé teszi egy napelemparkban található meghatározott számú panelre, vagy megtermelt energiamennyiségre történő feliratkozást. E megoldások megjelenéséből is látható, hogy az innováció kiemelt szerepet kap a napelemek piacán. Mindemellett, az adott üzleti modellt alkalmazó vállalatok menedzserei is kiemelt szerepet játszanak a sikeres adaptációban és müködtetésben, amelyhez esetükben fontos a vállalkozói szemlélet megjelenése, a lehetőségek folyamatos keresése, valamint olyan termékek és szolgáltatások fejlesztése, amelyek segítséget nyújthatnak a felmerülő akadályok leküzdésében (Hortoványi, 2012).

Az Amerikai Egyesült Államok világ szinten vezető pozíciót tölt be a napelemes üzleti modellek fejlesztésében és számos állam kiemelt szerepet vállal az új megoldások elterjedésének támogatásában. Ilyen példaként szolgálhat Kalifornia állam, ahol a három legnagyobb közmü- szolgáltató (Pacific \& Gas Electric, Southern California Edison és San Diego Gas \& Electric) garanciát vállalt 600 megawatt új közösségi napelemes kapacitás létesítésére 2019-ig (Trabish, 2015). Az ilyen jellegü törekvések és az innovatív üzleti modellek ösztönzőként szolgálhatnak azon országok számára, amelyek kihívásokkal néznek szembe a napelemek piacán, de ennek ellenére elkötelezettek a megújuló energiaforrások mellett.

E cikkben célunk szakirodalmi áttekintés alapján az alapvető napelemes üzleti modellek feltárása. Az áttekintés során azon koncepciók kerülnek bemutatásra, amelyek elsősorban lakossági fogyasztókat céloznak meg. Az egyes üzleti modellek fö elemeit a Business Model Canvas (BMC) keretrendszer kilenc építőeleme mentén vázoljuk fel, annak érdekében, hogy egy teljes képet adhassunk a modellekről és rávilágíthassunk az azonosítható különbségekre. A harmadik fél által tulajdonolt és a közösség által megosztott modell segítséget nyújthat azon régiók számára, amelyek napelemes piaca napjainkban még kevésbé fejlett, ezért a kulcselemek bemutatása támogatást nyújthat az adaptáció során. A következő lépésben hat szempontot határozunk meg, amelyek mentén a modellek jól elkülöníthetővé válnak egymástól. Végül pedig Osterwalder és Pigneur (2010) üzletimodell-definíciója alapján bemutatjuk mindhárom modell értékajánlatát, valamint az érték nyújtásának, megragadásának és teremtésének módját.

Összességében célunk, hogy támogassuk mind a politikai döntéshozókat, mind pedig a vállalatok vezetőit a fogyasztók problémáinak megértésében, az egyes modellek elterjedését gátló akadályok azonosításában, valamint olyan politikai, szabályozási és vállalati háttér kialakításában amely lehetővé teszi a megújuló energiaforrások lehető legszélesebb körben történő elterjedését.

\section{Üzleti modellek}

Az üzleti modell fogalma nem egy egységesen elfogadott definíción alapszik, de számos megközelítést fedezhetünk fel a szakirodalom áttekintése során. Magretta (2002) 
úgy tekint az üzleti modellekre, mint egy történet, amely elmeséli, hogy hogyan müködik a vállalat. Véleménye szerint - utalva ezzel Peter Drucker 1954-ben megjelent könyvére - egy jó üzleti modell választ ad azon kérdésekre, hogy „Kik a fogyasztók?”, „Mi jelenti számukra az értéket?” és „Hogyan lehet ezt az értéket megfelelő költségek mellett biztosítani?" Chatterjee (2013) megközelítése túlmutat azon, hogy az üzleti modell kizárólag arról szól, hogy a vállalat egy-egy termék vagy szolgáltatás értékesítésével profitot termeljen. A szerző véleménye alapján, alapvetően minden üzleti modell az értékajánlatból indul ki, amely folyamatosan fejlődik, és ezáltal versenyelőnyt biztosít a szervezet számára. Móricz $(2007,2009)$ szerint, „,az üzleti modell fö erénye, hogy a müködés alapvetö logikájában rejlö kulcstényezök közötti összefüggéseket világítja meg”. Barakonyi (2008) hangsúlyozta, hogy az üzleti modell sosem tekinthető befejezettnek, mivel magának a modell tesztelésének és a döntéshozatal folyamatának megszakítás nélkülinek és ismétlődőnek kell lennie. Mindezek mellett az üzleti modellek összességében hatékony módszert jelentenek a vállalatok vezetői számára, hogy stratégiai választásaikat, döntéseiket elemezhessék és ezzel párhuzamosan kommunikálhassák. Osterwalder és Pigneur (2010) üzletimodell-definíciója szerint, ,Az $\ddot{u} z$ leti modell azt irja le, hogy egy vállalkozás miként teremti, nyújtja és ragadja meg az értéket".

Cikkünkben Osterwalder és Pigneur definícióját tekintjük kiindulási pontnak, mivel megközelítésük jól alkalmazható a napelemes üzleti modellek bemutatására. Az üzleti modellek tárgyalása mellett továbbá fontosnak tartjuk kiemelni, hogy az új technológiák megjelenésével és az infokommunikációs technológiák fejlődésével párhuzamosan a vállalatok - többek között a nagy múltú energiaszolgáltatók - jelentős mértékben megújíthatják üzleti modelljüket, amelyekkel új piacokat, vevőket szerezhetnek meg és erősíthetik versenyelönyüket (Pateli - Giaglis, 2005; Wirtz - Schilke - Ullrich, 2010; Csath, 2012; Maglio - Spohrer, 2013). Üzletimodell-innováció alatt, Horváth, Móricz és Szabó (2018) meghatározása alapján a következőt értjük: „Üzletimodell-innovációnak tekintjük az ügyfeleknek nyújtott érték lényegi megújítását, a vállalat/hálózat folyamatainak és tevékenységrendszerének jelentös mértékü átalakitását, valamint a bevételi források és költségstruktúra újradefiniálását" (Horváth Móricz - Szabó, 2018).

\section{A Business Model Canvas}

A Business Model Canvas (továbbiakban BMC) keretrendszer kidolgozása, Alexander Osterwalder és Yves Pigneur nevéhez köthető. A szerzők a BMC-re mintegy az új, vagy már meglévő üzleti modellek vizualizációját lehetővé tevő vászonként tekintve, kilenc alapvető elem mentén ragadják meg a vállalatok felépítését, azok üzleti folyamatait. A BMC egy olyan közös nyelvet teremt meg, amelyet vezető vállalatok világszerte alkalmaznak. Az építőelemek teljesen lefedik az üzlet négy fö területét, amelyek a következők: fogyasztó, ajánlat, infrastruktúra és pénzügyi életképesség. A fogyasztói rész magá- ban foglalja a fogyasztói kapcsolatokat, csatornákat és fogyasztói szegmenseket. Az értékajánlat termékre és szolgáltatásokra utal, amelyek egy specifikus probléma megoldásán keresztül értéket teremtenek a fogyasztók számára. Végül pedig az infrastruktúra rész leírja az értékteremtéshez használt architektúrát, míg a pénzügyi aspektusok a bevételi csatornák és a költségszerkezet közötti kapcsolatot emelik ki (Osterwalder - Pigneur, 2010).

\section{Kutatásmódszertan}

Jelen kutatásunk szakirodalmi áttekintésen alapul. Webster és Watson (2002), valamint Von Brocke et al. (2009) iránymutatásait követve öt egymást követő lépést alkalmaztunk a szakirodalom áttekintése során: (1) a fókusz meghatározása, (2) a témakör fogalmi áttekintése, (3) szakirodalmi áttekintés, (4) irodalomelemzés és szintézis, valamint (5) véglegesítés.

1. Kutatásunk célja, hogy azonosítsuk és szintetizáljuk a világszinten azonosítható napelemes üzleti modelleket, ezáltal támogatva mind a modelleket alkalmazó vagy alkalmazni kívánó vállalatokat, befektetőket, valamint a fogyasztókat.

2. A témakör fogalmi áttekintése során azt találtuk, hogy a különböző üzleti modelleket tárgyaló kutatók rendszerint a Business Model Canvas keretrendszert alkalmazzák a koncepciók bemutatására. Ennek megfelelően, jelen kutatás során mi is ezt a keretrendszert alkalmazzuk. A használni kívánt keretrendszer meghatározása mellett, e szakaszban definiáltuk a szakirodalmi keresés föbb kulcsszavait.

3. A szakirodalmi keresés során az EBSCO adatbázist használtuk, tekintettel arra, hogy az adatbázis tartalmazza a legfontosabb folyóiratokat a gazdálkodástudomány, a menedzsment és az energetika területén. Első lépésként a cikkek címeiben, absztraktjaiban és kulcsszavaiban kerestünk, a következő kulcsszavak és azok kombinációjának alkalmazásával: „üzleti modell”, „,energia”, „megújuló”, ,alternatív”, „megosztott”, „napelem”, „fotovoltaikus”, „felhasználó által tulajdonolt”, „harmadik fél”, „közösség”. Második lépésként átvizsgáltuk a publikációkban használt hivatkozásokat, annak érdekében, hogy még átfogóbb képet kaphassunk a vizsgált koncepciókról.

4. A negyedik fázisban, az összegyüjtött publikációkat különböző csoportokba osztottuk fel az alkalmazott kutatásmódszertan és a vizsgált modellek alapján. Szintén ebben a fázisban zártuk ki azon cikkeket, amelyek nem álltak szoros kapcsolatban az általunk vizsgált területekkel (pl. az energiatermelés modellezésével foglalkozó publikációk). Palvia et al. (2004) és Cardenas et al. (2014) alapján, a következő kutatás-módszertani kategóriákat definiáltuk a megtartott cikkek között: felmérés, interjú, terepkutatás, esettanulmány, 
irodalomelemzés, keretrendszerek és konceptuális modellek. Ezt követően a publikációkat felosztottuk a jelen cikkükben is alkalmazott üzletimodell-típusok szerint: felhasználó által tulajdonolt, harmadik fél által tulajdonolt és közösség által megosztott.

5. Az utolsó lépésben minden cikket kategorizáltunk a korábban kialakított szempontok szerint, majd a Business Model Canvas keretrendszer alkalmazásával áttekintettük az azonosított modelleket.

\section{Az alapvető napelemes üzleti modellek azonosítása}

Az elemzett cikkekben a két általános üzleti modell mellett - felhasználó és harmadik fél által tulajdonolt megfigyelhető a közösség által megosztott modell elterjedése. A következőekben a kapcsolódó publikációkból szerzett információk alapján a Business Model Canvas alkalmazásával bemutatjuk e modellek fö jellemzőit, a modellt müködtető vállalatok szemszögéből. A szakirodalmi áttekintéssel célunk, hogy egy átfogó képet adjunk az azonosított üzleti modellekről, illetve ezáltal hozzájáruljunk a koncepciók és a kapcsolódó fogalmak jobb megértéséhez. Az üzletimodell-leírásokat két részre bontottuk, a Business Model Canvas fogyasztói, illetve infrastruktúra oldalára. Az alkalmazott keretrendszer fogyasztói oldala magában foglalja az értékajánlatot, a fogyasztói kapcsolatokat, fogyasztói szegmenseket, csatornákat és bevételi forrásokat, míg az infrastruktúra oldala a kulcspartnereket, kulcstevékenységeket, kulcserőforrásokat, valamint a költségstruktúrát (Osterwalder - Pigneur, 2010).

\section{A felhasználó által tulajdonolt üzleti modell}

A napelemes üzleti modellek fejlődéstörténetének áttekintése alapján, a felhasználó által tulajdonolt modell tekinthető a legkorábbinak és legelterjedtebbnek. A modell számos elnevezéssel azonosítható az elemzett tanulmányokban, amelyek a következők: Customer-owned (Huijben - Verbong, 2013; Karakaya, Nuur - Hidalgo, 2016), Host-owned (Zhang, 2016) Host-owned feed-in (Strupeit - Palm, 2016), Customer-sited (Huijben - Verbong, 2013), End-user owner (Frantzis et al., 2008). A modell bemutatása során a Felhasználó által tulajdonolt elnevezést alkalmazzuk. A koncepció keretében a napelemes rendszert azon fogyasztó ingatlanán kivitelezik, aki a jövőben használni fogja a rendszer által megtermelt energiát. Az üzleti modell építőelemeinek áttekintése az 1. táblázatban látható.

\section{Fogyasztói oldal}

\section{Értékajánlat}

Az értékajánlat bemutatása során leírjuk, hogy az adott üzleti modell keretein belül hogyan teremtődik érték a célszegmensek számára a termékek és szolgáltatások értékesítésén keresztül. A felhasználó által tulajdonolt modell esetében a vállalatok rendszerint értékesítenek mind előre rögzített tartalmú csomagokat, amelyek meghatározott elemeket tartalmaznak (pl. inverter, napelempanel, kábelek) és összetételükön a fogyasztó nem módosíthat, mind pedig nem fix összetételü csomagokat. A nem rögzített tartalmú csomagok lehetővé teszik a fogyasztók számára, hogy azok tartalmát saját igényeik szerint alakítsák (Huijben - Verbong, 2013; Karakaya - Nuur - Hidalgo, 2016; Zhang, 2016). A napelemes rendszer telepítése a csomagokat értékesítő vállalat által történik, de néhányuk lehetővé teszi, hogy a fogyasztó saját maga telepítse a rendszert. Emellett, a modell esetében az értékajánlat jelentős részét képezi, hogy a fogyasztók függetleníthetik magukat az energiaközmüvektől azáltal, hogy úgynevezett termelő fogyasztókká (prosumer) válnak, akik saját maguk számára termelik meg a szükséges villamos energiát és ezáltal csökkenthetik energiaszámlájukat (Sommerfeldt - Muyingo - Klintberg, 2016). A beruházási döntések esetén szintén fontos szerepet játszhat, hogy az adott ország szabályozási rendszere alapján, a fogyasztók a megtermelt energia hálózatra való visszatáplálásával a meghatározott átvételi árnak megfelelően díjfizetésben részesülhetnek az áramszolgáltatóktól, az úgynevezett betáplálási tarifák (feed-in tarrifs) szerint. A betáplálási tarifáknak köszönhetően a beruházások egy olyan kedvező megtérülési szintet érhetnek el, amelyek versenyképessé válnak más befektetési lehetőségekkel (Couture et al., 2010; Hashim - Ho, 2011; Solangi et al., 2011). A betáplálási tarifák ezáltal jelentős mértékben csökkenthetik a befektetési kockázatokat és támogathatják a megújuló energiaforrások elterjedését, amely a politikai döntéshozók számára egy egységes támogatási rendszer kidolgozását és alkalmazását irányozza elő (Couture et al., 2010; Strupeit - Palm, 2016). Az adott ország szabályozásától függően a lakossági fogyasztók szintén részesülhetnek adókedvezményekben, kezdeti beruházási támogatásban, vagy egyéb speciális pénzügyi támogatási programokban (Frantzis et al., 2008; Nemzeti Fejlesztési Minisztérium, 2016; Zhang, 2016).

\section{Fogyasztói kapcsolatok}

Mivel a fogyasztói tudatosság és technológiai elfogadási kérdések jelentős kihívásokat generálnak a megújuló energiához kapcsolódó megoldásokat értékesítő vállalatok számára, ezért a megfelelő ügyfélkapcsolatok kiépítése fontos szerepet játszik a kölcsönös bizalom megteremtésében és a hosszú távú fogyasztói kapcsolatok megalapozásában. Ennek megfelelően számos vállalat alakít ki közvetlen kapcsolatot ügyfeleivel, személyes csatornák alkalmazásán keresztül (Huijben - Verbong, 2013). Ilyen személyes kapcsolatlétesítés lehet például az árajánlat elkészítése előtt a fogyasztónál a vállalat értékesítési képviselője által tett személyes látogatás a napsütési potenciál meghatározása, a tetőfelület és a fogyasztói preferenciák felmérése érdekében (Huijben - Verbong, 2013; Karakaya - Nuur - Hidalgo, 2016). Ezenkívül számos vállalat támaszkodik szájreklámra, amely pozitív iránya esetén hozzájárulhat a hitelesség növeléséhez, valamint az online kapcsolattartási formák 
között rendszerint megjelenik a vállalati weboldal használata (Strupeit - Palm, 2016).

\section{Fogyasztói szegmensek}

A fogyasztói szegmensek blokkban meghatározzák azokat a legfontosabb fogyasztói csoportokat, amelyeket a vállalatok a felhasználó által tulajdonolt modell keretében megkívánnak célozni. A kapcsolódó kutatásokban a fogyasztói szegmensekre vonatkozóan csak pár általános megnevezést találhatunk, az egyes szegmensek jellemzőit nem mutatják be részletesen. Egyik legfontosabb szegmensként azon kertesház-tulajdonosok azonosíthatók, akiknek ingatlanukon megfelelő tetőfelület áll rendelkezésre a napelemes rendszer telepítéséhez és rendelkeznek a beruházáshoz szükséges pénzösszeggel (Huijben - Verbong, 2013; Strupeit - Palm, 2016). A lakossági szegmens esetében a telepített rendszerek mérete rendszerint $10 \mathrm{~kW}_{\mathrm{p}}$-ig terjed (Dewald - Truffer, 2011). E fogyasztók korai elfogadóként jellemezhetők, akik esetében fö motivációs tényezőként az energiafüggetlenség és a környezeti előnyök azonosíthatók (Frantzis et al., 2008). A szegmens jelentős részét olyan úttörö ügyfelek alkotják, mint például energetikai mérnökök és elkötelezett környezetvédők (Zhang, 2016) (DSPV, azonban életstílusukról, társadalmi és családi állapotukról, attitűdjükről és további jellemzőikről nem tájékozódhatunk az elemzett kutatásokban. További jellemző fogyasztókként azonosíthatók például a mezőgazdasági termelők, valamint a kis- és középvállalkozások (Munasinghe, 1990; Strupeit - Palm, 2016).

\section{Csatornák}

Az azonosított csatornák szorosan kötődnek a fogyasztói kapcsolatokhoz. A személyes csatornák alkalmazása kulcsszerepet játszik a bizalomépítésben és a fogyasztói elköteleződésben. A vállalatok értékesítési képviselői kiemelt szerepet játszanak a személyes csatornáknál, mivel ök találkoznak először a potenciális ügyfelekkel (Huijben - Verbong, 2013; Karakaya - Nuur - Hidalgo, 2016). Ez a kezdeti interakció pedig jelentős mértékben meghatározhatja a céggel való teljes kapcsolatot és az ajánlat kiválasztását. A személyes csatornák alkalmazására jó példaként szolgálhat a Hartmann Energietechnik $\mathrm{GmbH}$ (HET) által minden hónapban megtartott úgynevezett napelemes séta. A séták során a potenciális fogyasztók számos olyan referenciaingatlant látogatnak meg, amelyek esetében a napelemes rendszer telepítése a HET által történt (Karakaya - Nuur - Hidalgo, 2016). Szintén követhetö jó gyakorlatként szolgálhat a decentralizált energiapiacon müködő vállalatok számára a SolarCity nagykövet programja, amely egyben kiváló példája a többszintű marketingnek. A program keretében a fogyasztók ajánlhatják a SolarCity-t más potenciális fogyasztóknak, és amennyiben az ajánlott fogyasztó napelemes rendszert vásárol, az ajánló díjfizetésben részesül. Magyarországon szintén találkozhatunk ilyen ajánlói programmal, amely az enHome Napkövet nevet viseli (ELMÜ-ÉMÁSZ Társaságcsoport). Az ajánlói programok mellett a szájról szájra terjedő kommuniká- ció szintén jelentős hatással van a fogyasztók befektetési döntéseire (Seel - Barbose - Wiser, 2014). A vállalati weboldalak és speciális napelemes kiadványok alkalmazása egyaránt azonosítható az alapvető csatornák között, lehetővé téve a napelemes vállalat számára, hogy tájékoztassa potenciális ügyfeleit termék- és szolgáltatásportfóliójáról (Strupeit - Palm, 2016).

\section{Bevételi források}

A modell esetében a fó bevételi forrást a napelemes rendszerek telepítésének díja jelenteni. A bevételi források kisebb része olyan kiegészítő szolgáltatásokból származik, mint például a rendszerek karbantartása és javítása (Schoettl - Lehmann-Ortega, 2011; Karakaya Nuur - Hidalgo, 2016; Strupeit - Palm, 2016). Mindezek mellett, számos vállalat nyújt testreszabott, értéknövelt szolgáltatásokat saját tudásbázisuk hasznosításával, energetikai tanácsadáson keresztül (Strupeit - Palm, 2016). Végül pedig olyan esetekkel is találkozhatunk, ahol a napelemes paneleket közvetlenül értékesítik a végfelhasználóknak, kiegészítő szolgáltatások nyújtása nélkül (Frantzis et al., 2008).

\section{Infrastruktúra oldal}

\section{Kulcspartnerek}

A vállalatok legfontosabb kulcspartnerei rendszerint a napelemes rendszerek komponenseinek - például inverter, napelempanel, tartószerkezet - gyártói, kereskedői, akik az értékesítés mellett technikai, marketing- és projektspecifikus tudással is támogatják őket (Strupeit Palm, 2016). Ezekből adódóan elengedhetetlen, hogy a vállalatok stabil kapcsolatot alakítsanak ki kulcspartnereikkel az állandó termékellátás biztosítása és alkupozíciójuk erősítése érdekében. Az elektromos hálózathoz való csatlakozás engedélyezőként kiemelendő továbbá az elektromos közműszolgáltatók, valamint bizonyos vállalatok esetében a finanszírozási megoldásokat (például kölcsön) biztosító bankok szerepe a kulcspartnerek között (Frantzis et al., 2008; Strupeit - Palm, 2016).

\section{Kulcstevékenységek}

A teljes körü szolgáltatás-portfólióval összhangban, a vállalatok fő tevékenysége rendszerint kulcsrakész megoldások nyújtására terjed ki. A kulcsrakész megoldás magában foglalja a rendszerek tervezését, a szükséges engedélyek megszerzését, a rendszerkomponensek beszerzését, a rendszer telepítését, a teljesítmény monitorozását, illetve amennyiben szükséges a javítást és karbantartást (Schoettl - Lehmann-Ortega, 2011; Karakaya - Nuur - Hidalgo, 2016; Strupeit - Palm, 2016). A kulcsrakész megoldások mellett számos vállalat foglalkozik különálló tevékenységként napelemes panelek értékesítésével, vagy olyan értékesítés utáni szolgáltatások nyújtásával, mint a rendszer teljesítményének felügyelete és javítása. A tevékenységszerkezetben egyaránt azonosítható a tanácsadási tevékenység, amely finanszírozási, támogatási és ösztönzési rendszerek ismertetésére, adózási kérdések megválaszolására és megújuló ener- 
giához kapcsolódó megoldások bemutatására terjed ki. Összességében tehát látható, hogy ügyféltámogató szolgáltatások szintén megjelennek a kulcstevékenységek között (Frantzis et al., 2008; Huijben - Verbong, 2013; Strupeit - Palm, 2016). A befektetési kockázat csökkentése, valamint a fogyasztók biztonságérzetének növelése érdekében, egyes piaci szereplők tevékenységei között azonosítható továbbá a napelemes rendszerre vonatkozó biztosítás nyújtása (Huijben - Verbong, 2013). Szintén ehhez az építőelemhez sorolandó a beszállítók kiválasztása, illetve ártárgyalások lebonyolítása, mivel a vállalatok rendszerint különböző gyártóktól és kereskedőktől szerzik be a rendszerkomponenseket (Huijben - Verbong, 2013; Strupeit - Palm, 2016). Végül a vállalatok rendszerint aktív marketingtevékenység keretében törekednek hírnevük növelésére, illetve az ügyfélkapcsolatok erösítésére (Frantzis et al., 2008).

\section{Kulcseröforrások}

A decentralizált energiapiacon működő vállalatok számára elengedhetetlen kulcserőforrásként jelentkezik a technológiai tudás, a szakértői személyzet, valamint munkavállalóik saját tudásbázisa (Huijben - Verbong, 2013; Strupeit - Palm, 2016). Következtetésképpen, a vállalatok humántőkéje fontos szerepet játszik a versenyképesség és a jövőbeli kilátások terén. Emellett a helyi piacok és a fogyasztók szoros ismerete rendszerint azokra a vállalatokra jellemző, akik napi kapcsolatban állnak ügyfeleikkel és ezáltal jelentős információkra tehetnek szert az egyes szegmensek preferenciáira, valamint életstílusára vonatkozóan (Karakaya - Nuur - Hidalgo, 2016; Strupeit - Palm, 2016). Karakaya, Nuur és Hidalgo (2016) szerint a vállalatok láthatósága, amelyet társadalmi és marketingtevékenységeken keresztül érhetnek el, erősen befolyásolhatja a fogyasztók érdeklődését. Összegezve, a leírt tényezők jelentősen hozzájárulhatnak a vállalati arculat építéséhez (Frantzis et al., 2008).

\section{Költségstruktúra}

$\mathrm{Az}$ elemzett irodalmakban rendszerint nem mutatták be a vállalati oldalon felmerülő költségeket, azonban számos következtetés vonható le a Business Model Canvas további részei alapján. Az ügyfélkapcsolatok kezelésében kiemelt szerepet játszanak az értékesítési képviselők, valamint a szakértői személyzet alkalmazása elengedhetetlen a hatékony müködéshez. Ebből adódóan az értékesítési költségek és bérkifizetések a költségek lényeges elemeiként azonosíthatók. A márkaépítéshez köthető marketingkiadások vélhetően szintén jelentős arányt képviselnek a költségstruktúrában. A készlettartási költségek - például a napelemes rendszer komponenseinek, inverterek, panelek és tartóeszközök készletezése -, a készletgazdálkodási és a raktározási költségek egyaránt számottevőek lehetnek.
1. táblázat

Business Model Canvas: felhasználó által tulajdonolt üzleti modell

\begin{tabular}{|c|c|}
\hline \multicolumn{2}{|l|}{ Fogyasztói oldal } \\
\hline Értékajánlat & $\begin{array}{l}\text { - rögzített tartalmú csomagok } \\
\text { • nem rögzített összetételú csomagok } \\
\text { • lehetőség a rendszer egyénileg történő } \\
\text { telepítésére } \\
\text { • közmüszolgáltatóktól való függetlenség } \\
\text { • csökkentett energiaszámla } \\
\text { • versenyképes befektetési lehetőség }\end{array}$ \\
\hline $\begin{array}{l}\text { Fogyasztói kap- } \\
\text { csolatok }\end{array}$ & $\begin{array}{l}\text { - közvetlen interakciók, személyes } \\
\text { kapcsolatok } \\
\text { • szájreklám } \\
\text { • online kapcsolattartási formák }\end{array}$ \\
\hline $\begin{array}{l}\text { Fogyasztói szeg- } \\
\text { mensek }\end{array}$ & $\begin{array}{l}\text { - ingatlantulajdonosok } \\
\text { • mezőgazdasági termelők } \\
\text { • kis- és középvállalkozások } \\
\end{array}$ \\
\hline Csatornák & $\begin{array}{l}\text { - értékesítési képviselök } \\
\text { • különböző személyes csatornák pl. } \\
\text { napelemes séták } \\
\text { • vállalati weboldal } \\
\end{array}$ \\
\hline Bevételi források & $\begin{array}{l}\text { - napelemes rendszer telepítése } \\
\text { - karbantartás } \\
\text { - javítás } \\
\text { - energetikai tanácsadás } \\
\text { - napelempanelek értékesítése }\end{array}$ \\
\hline \multicolumn{2}{|c|}{ Infrastruktúra oldal } \\
\hline Kulcspartnerek & $\begin{array}{l}\text { - rendszerkomponensek gyártói } \\
\text { - rendszerkomponensek nagykereskedői } \\
\text { • közmüszolgáltatók } \\
\text { - bankok }\end{array}$ \\
\hline $\begin{array}{l}\text { Kulcstevékeny- } \\
\text { ségek }\end{array}$ & $\begin{array}{l}\text { - kulcsrakész megoldások } \\
\text { - napelempanelek értékesítése } \\
\text { - értékesítés utáni szolgáltatások } \\
\text { - ügyféltámogató szolgáltatások } \\
\text { - napelemesrendszer-biztosítás } \\
\text { - ártárgyalás } \\
\text { - szállítók kiválasztása } \\
\text { - marketingtevékenységek }\end{array}$ \\
\hline Kulcserőforrások & $\begin{array}{l}\text { - humántőke (pl. szakértő személyzet) } \\
\text { - helyi piacok szoros ismerete } \\
\text { - fogyasztók szoros ismerete } \\
\text { - vállalatok láthatósága } \\
\text { - márkaarculat }\end{array}$ \\
\hline Költségstruktúra & $\begin{array}{l}\text { - értékesítési költségek } \\
\text { - munkabérek } \\
\text { - készletköltség } \\
\text { - készletezési és raktározási költségek }\end{array}$ \\
\hline
\end{tabular}
Forrás: saját szerkesztés

\section{Harmadik fél által tulajdonolt üzleti modell}

A harmadik fél által tulajdonolt modell esetében a következő elnevezéseket azonosítottuk: Third-party (Kollins - Speer - nCory, 2010), Third-parties (Brunekreeft - Buchmann - Meyer, 2016), Third-party owner (Frantzis et al., 2008), Third-party ownership (Kollins, 2008; Bolinger, 2009; Coughlin - Cory, 2009; NREL, 2009; Ardani - Margolis, 2010; Kollins - Speer - Cory, 2010; Hobbs - Pierpont, 2013; Corfee et al., 2014; Overholm, 2015; Berger, 2016; Strupeit - Palm, 2016; Zhang, 2016), 
Third-party-owned (Davidson - Steinberg, 2013; Davidson - Steinberg - Margolis, 2015), Third party PV (Huijben - Verbong, 2013), Solar City model (Zhang, 2016), Third-party financing (Thumann - Woodroof, 2008; Feldman - Friedman - Margolis, 2013; Zhang, 2016). A következetesség érdekében a továbbiakban a harmadik fél által tulajdonolt modell megnevezést használjuk.

A harmadik fél által tulajdonolt modell 2005-ben jelent meg először az Amerikai Egyesült Államokban (Överholm, 2013). A konstrukció kedvező kialakításának köszönhetően ma már számos országban találkozhatunk a modell különböző változataival, mint például Hollandiában, Dániában, Kínában és Németországban (Huijben Verbong, 2013; Brunekreeft - Buchmann - Meyer, 2016; Strupeit - Palm, 2016; Zhang, 2016). Az Egyesült Államokban a Sun Edison és az MMA Renewable Ventures vállalatok alkalmazták elöször ezt a modellt, majd rövid időn belül számos más vállalat is követte őket (Kollins, 2008). Ezek a cégek jellemzően energiavásárlási szerződéseket (EVSZ) vagy lízingmegoldásokat értékesítenek. Az EVSZ története azonban már jóval korábbra nyúlik vissza a modell 2005-ös első alkalmazásához képest. Az EVSZ-t eredetileg energiaközmüvek alkalmazták, az egymás közötti energiavásárlási tranzakciók lebonyolítása érdekében. Az 1978-as amerikai közmüszabályozási törvény (Public Utility Regulatory Policies Act, PURPA) arra kötelezte a közmüszolgáltatókat, hogy a szükséges energiamennyiséget ún. minősített létesítményektől vásárolják meg. A közmüvek és a független termelők (minősített létesítmények) e tranzakciók lebonyolítására alkalmazták az energiavásárlási szerződéseket (Kollins, 2008; Kollins - Speer - Cory, 2010).

A harmadik fél által tulajdonolt modell segítségével a lakossági fogyasztók számára lehetőség nyílik számos pénzügyi akadály, pl. a kezdeti magas befektetési költségek kiküszöbölésére. Az elönyöknek köszönhetően a modell gyorsan terjedni kezdett, és az USA-ban 2014ben lakossági fogyasztók számára értékesített napelemes rendszerek 72\%-át EVSZ, vagy lízingkonstrukció keretében adták el. A GTM Research alapján azonban látható, hogy 2015-ben ez az arány csökkenni kezdett, valamint az elörejelzések szerint 2020-ig ismét a felhasználók által tulajdonlás lesz domináns a lakossági szegmens esetében (GTM Research, 2015). Ez a visszaesés az Amerikai Egyesült Államokban három fó okra vezethető vissza: (1) hitellehetőségek bővülése, (2) a harmadik fél által tulajdonolt modell üzemeltetőit kiszolgáló beszállítók hiánya, (3) valamint a SolarCity vállalat, aki a modell fő hajtója volt, már nem fektet bele több energiát a modell népszerüsítésébe (Mond, 2017). Az üzleti modell elemei a 2. táblázatban láthatók.

\section{Fogyasztói oldal}

\section{Értékajánlat}

A kezdeti magas befektetési költségek, a pénzügyi erőforrások hiánya, valamint a hosszú megtérülési idő erősen befolyásolhatja a napelemes rendszerek iránti keresletet. Ebből adódóan, a harmadik fél által tulajdonolt modell esetében a legnagyobb előnyként az a tényező azonosítható, hogy a fogyasztóknak lehetőségük nyílik napenergia használatára a kezdeti költségek megfizetése nélkül (Zhang, 2016). A konstrukció keretében a villamosenergia-számla megtakarítás már az első hónapban várható, a fogyasztóknak nem kell aggódniuk a hosszú megtérülési időszak miatt, valamint olyan áron juthatnak zöldenergiához, ami jóval versenyképesebb, mint a villamos energia ára (Drury et al., 2012; Hobbs - Pierpont, 2013; Zhang, 2016). Mindent egybevetve, az értékajánlat jelentős részeként azonosítható, hogy az energiaköltség kiszámíthatóvá válik a szerződés teljes időtartamára (legfeljebb 25 évig) és a finanszírozási konstrukciók lehetővé teszik a fogyasztók számára, hogy elkerüljék az ingadozó villamosenergia-árakat (NREL, 2009; Strupeit - Palm, 2016) hangsúlyozta továbbá, hogy a napelemes szolgáltató cégek további előnyöket generálhatnak ügyfeleik számára azáltal, hogy képesek kezelni a komplex szabályozási rendszerekhez kapcsolódó magas tranzakciós költségeket.

Az EVSZ esetében a karbantartási felelősség nem a fogyasztóra, hanem a szolgáltató cégre helyeződik (Thumann - Woodroof, 2008; Coughlin - Cory, 2009; Ardani - Margolis, 2010; Eley, 2016). Ezzel szemben a lízingszerződéseknél a fogyasztó válik felelőssé a fenntartási tevékenységek elvégzéséért, de ennek ellensúlyozása érdekében a lízingszolgáltatók rendszerint olyan teljesítménygaranciát és karbantartási csomagokat ajánlanak, amelyek jelentősen csökkentik a technológiai kockázatot és a felmerülő karbantartási feladatok számosságát (Kollins - Speer - Cory, 2010). Ezen túlmenően, bizonyos konstrukciók keretében a vállalatok lehetővé teszik, hogy a fogyasztók saját maguk telepítsék a napelemes rendszert (Huijben - Verbong, 2013).

\section{Fogyasztói kapcsolatok}

A harmadik fél által tulajdonolt modell esetében, a napenergia szolgáltató cégek hosszú távra szóló kapcsolatot építenek ki fogyasztóikkal az energiavásárlási és lízingszerződéseken keresztül. Ebből adódóan létfontosságúvá válik a személyes kapcsolatok kialakítása, valamint a fogyasztói kapcsolatok erősítése több csatorna alkalmazásán keresztül. Ilyen csatornákként szolgálhatnak többek között a társadalmi tevékenységek és események, az értékesítő munkatársak, a fogyasztói kiállítások, valamint a kiemelt vállalati ügyfélszolgálat kiépítése (Strupeit Palm, 2016). Az online kapcsolattartási formák alkalmazása szintén közös vonásként azonosítható az előző modellhez viszonyítva (Huijben - Verbong, 2013).

\section{Fogyasztói szegmensek}

A modell esetében azon háztartások tekinthetők az egyik legjelentősebb szegmensnek, amelyek nem engedhetik meg maguknak a magas, kezdeti telepítési költségek megfizetését, de ennek ellenére szándékukban áll villanyszámlájuk csökkentése és fontos számukra a környezet védelme (Huijben - Verbong, 2013; Strupeit - Palm, 2016; Zhang, 2016). Drury és szerzőtársai (2012) szerint, a koncepció szintén vonzó azon fiatalabb fogyasztók számára, akik alacsonyabb képzettséggel és kevésbé stabil anyagi 
háttérrel rendelkeznek. A szegmensek között azonosíthatók továbbá mezőgazdasági termelők, vállalatok és állami szervezetek (Drury et al., 2012; Huijben - Verbong, 2013; Strupeit - Palm, 2016). Amennyiben nem csak az energia végfelhasználóit nézzük, akkor elmondható, hogy a napelemes szolgáltatók olyan magán- és közbefektetőket is megcéloznak, amelyek befektetéseik révén a rendszerek technikai tulajdonosává válnak és ezáltal részesülhetnek a szerződéses kifizetésekből, továbbá az állami támogatásokból (Frantzis et al., 2008).

\section{Csatornák}

A fogyasztó által tulajdonolt modellhez hasonlóan a vállalatok értékesítő munkatársai ezen modell esetében is kiemelt szerepet játszanak a csatornák között. A napelemes szolgáltató cégek értékesítői tájékoztathatják a potenciális ügyfeleket a modell segítségével realizálható előnyökről, valamint erösíthetik a fogyasztói kapcsolatokat. Emellett a szolgáltatók gyakran vesznek részt konferenciákon, valamint egyéb szakmai eseményeken (például energiaipari konferenciákon és fogyasztói kiállításokon), ezzel is törekedve hálózatuk bővítésére. Szintén kiemelendő a különböző marketingeszközök alkalmazása - mind online és offline platformokon -, valamint az aktív médiakapcsolatok jelentősége (Frantzis et al., 2008). Végül pedig itt is megjelenik a vállalati weboldalak használata a termékek és szolgáltatások, valamint a finanszírozási megoldások ismertetésének érdekében (Huijben - Verbong, 2013).

\section{Bevételi források}

A harmadik fél által tulajdonolt modell esetében a bevétel jelentős része az energiavásárlási szerződésekből, vagy pedig a lízingszolgáltatásokból származik. Az EVSZ-konstrukció keretében a fogyasztó által fizetendő összeget a megtermelt energia mennyisége alapján határozzák meg (Ft/kWh) (Feldman - Friedman - Margolis, 2013; Davidson - Steinberg - Margolis, 2015; Eley, 2016; Zhang, 2016). Az energiavásárlási szerződések időtartama rendszerint vállalatonként eltérő, de érvényességük általában 10-25 éves periódusra szól (Frantzis et al., 2008; Kollins - Speer - Cory, 2010; Feldman - Friedman - Margolis, 2013). A lejárat után a fogyasztó három opció közül választhat: (1) lehetőség nyílik a rendszer megvásárlására, (2) a szerződés megújítására, vagy (3) a teljes rendszer eltávolítására (Kollins - Speer - Cory, 2010; Corfee et al., 2014). A napelemes lízing esetében a fogyasztó nem az elöállított energia mennyisége alapján fizet, hanem a rendszert lízingeli és használja a megtermelt energiát, tehát a fizetési kötelezettség egyfajta havi ,bérleti díjként” jelentkezik (Huijben - Verbong, 2013; Davidson - Steinberg Margolis, 2015; Strupeit - Palm, 2016). A lízingmegoldás igénybevétele elsősorban az Amerikai Egyesült Államok azon államaiban jellemző, ahol az EVSZ-t nem engedélyezték (Ardani - Margolis, 2010).

A napenergia szolgáltató cégek további bevételi forrásaként azonosíthatók a kormányzati támogatások, állami és szövetségi (USA) ösztönzők, valamint az önkormányzatok és a helyi közművek által folyósított támogatási formák (Davidson - Steinberg, 2013; Hobbs - Pierpont, 2013;
Sherwood, 2014). Emellett az USA bizonyos államaiban a rendszerek tulajdonosai részesülhetnek olyan adókedvezményekben, mint például a beruházási adókedvezmény és a gyorsított értékcsökkenés (Bolinger, 2009; NREL, 2009; Berger, 2016). A beruházási adókedvezmény lehetővé teszi, hogy a napelemes rendszerek teljes befektetési összegének 30\%-a adójóváírásként érvényesítésre kerülhessen, míg a gyorsított értékcsökkenés alkalmazásával a rendszerek múködésének első öt évében teljes értékcsökkenés számolható el (NREL, 2009; Corfee et al., 2014). Az USA azon államaiban, ahol érvényben van a megújuló portfóliószabvány (Renewable Portfolio Standard, RPS), amely megújuló energiaforrásokból származó megnövekedett energiatermelést ír elő, a napelemes szolgáltatók további bevételt generálhatnak a megújuló energia tanúsítványok értékesítéséből (Hurlbut - McLaren - Gelman, 2013). Végül, de nem utolsósorban a vállalatok tevékenységi körének függvényében a bevételi források között megjelennek a fejlesztési, monitorozási és egyéb szolgáltatási díjak is (Huijben - Verbong, 2013; Zhang, 2016).

\section{Infrastruktúra oldal}

\section{Kulcspartnerek}

Egyes bankok és nagyvállalatok jelentős pozíciót tölthetnek be a kulcspartnerek között azáltal, hogy pénzügyi támogatást nyújtanak a napenergia szolgáltató cégek EVSZ és lízing üzleti modelljeihez, ezáltal hozzájárulva a projektalapok finanszírozásához (Frantzis et al., 2008; Zhang, 2016). A felhasználó által tulajdonolt modellhez hasonlóan, ebben a modellben is kiemelt szerepet kapnak az energiaszolgáltatókkal, a napelemes rendszerkomponensek gyártóival és nagykereskedőivel kialakított partneri kapcsolatok. További partnerek lehetnek tanácsadócégek, ügyvédi irodák, biztosítók, valamint telepítő és karbantartó cégek (Overholm, 2015; Strupeit - Palm, 2016).

\section{Kulcstevékenységek}

A harmadik fél által tulajdonolt modell esetében számos kulcstevékenység azonosítható az elemzett kutatásokban. A következőkben a szerzők bemutatják azon fötevékenységeket, amelyek közösnek tekinthetök a napenergia szolgáltató cégek esetében.

A konstrukció keretében a legfontosabb tevékenységként lízingmegoldások nyújtása és energiavásárlási szerződések kötése áll (Davidson - Steinberg, 2013; Strupeit - Palm, 2016; Zhang, 2016). A lízingszolgáltatást kínáló cégek rendszerint oly módon szervezik meg a projektek finanszírozását, hogy több beruházás egy befektetési alapba történő összegyüjtésével értékesítik azt befektetők számára, amely a lízingcégek részéről alapkezelési funkciók betöltését teszi szükségessé (Hobbs - Pierpont, 2013). A felhasználó által tulajdonolt modellhez hasonlóan ennél a koncepciónál is megjelenik alaptevékenységként a kulcsrakész megoldások nyújtása, amely magában foglalja a rendszerek kivitelezését és olyan kiegészítő szolgáltatások nyújtását, mint a szükséges engedélyek beszerzése (pl. csatlakozási engedély), a közműszolgáltatókkal való kapcsolattartás, az elérhető támogatásokhoz kapcsolódó 
ügyintézés, rendszerteljesítmény monitorozása, karbantartás és szervizelés (NREL, 2009; Drury et al., 2012; Huijben - Verbong, 2013; Zhang, 2016). Az USA egyes államaiban további kulcstevékenységként azonosítható a megújulóenergia-tanúsítványok értékesítése (Hurlbut, McLaren - Gelman, 2013). A szolgáltatásokhoz kapcsolódó kulcstevékenységek mellett azonosítható továbbá a marketingeszközök aktív használata, a különböző médiumokon és kiegészítő csatornákon való megjelenésekkel (Frantzis et al., 2008).

\section{Kulcserőforrások}

A harmadik fél által tulajdonolt üzleti modell esetében a meglévő fogyasztói bázis kiemelt szerepet játszik a kulcserőforrások között, lehetővé téve a vállalatok számára, hogy még ismertebbé váljanak és bővítsék hálózatukat. A modellhez összetett projektmenedzsment-feladatok kapcsolódnak, így a napenergia szolgáltató cégek számára elengedhetetlenné válik az olyan szoftverek birtoklása, amelyek támogatást nyújtanak értékesítési, projektmenedzsment és rendszerteljesítmény monitorozási területeken. (Strupeit - Palm, 2016). A modell komplexitásának kezeléséhez egyaránt fontossá válik a megfelelő pénzügyi és technológiai szakértelemmel rendelkező, jól képzett munkatársak alkalmazása (Frantzis et al., 2008; Huijben - Verbong, 2013).

\section{Költségstruktúra}

A fogyasztó által tulajdonolt modellhez hasonlóan a kapcsolódó irodalmakban e modell esetében sem részleteztük a vállalati oldalon jelentkező költségeket, azonban a Business Model Canvas további részei alapján meg lehet határozni néhány főbb költségelemet. Először is feltételezhető, hogy a kiadások jelentős része az EVSZ és lízingkonstrukciók kezeléséhez köthető, beleértve a magán- és közbefektetők megszerzését a munkaerő- és IT-költségeken keresztül. További általános költségelemekként azonosíthatók az értékesítési, marketing-, készlet- (napelempanelek, inverterek stb.) és raktározási költségek.

\section{Business Model Canvas: harmadik fél által tulajdonolt üzleti modell}

\begin{tabular}{|c|c|}
\hline \multicolumn{2}{|c|}{ Fogyasztói oldal } \\
\hline Értékajánlat & $\begin{array}{l}\text { - nincsen kezdeti telepítési költség } \\
\text { • azonnali energiamegtakarítás (csökken- } \\
\text { tett energiaszámla) } \\
\text { • zöldenergia versenyképes áron } \\
\text { • kiszámítható villamosenergia-ár } \\
\text { • komplex szabályozási rendszerekhez } \\
\text { kapcsolódó magas tranzakciós költségek } \\
\text { kezelése } \\
\text { - üzemeltetési és karbantartási felelösség } \\
\text { áthelyezése (EVSZ) } \\
\text { - csökkentett technológiai kockázat } \\
\text { - lehetőség a rendszer egyénileg történő } \\
\text { telepítésére }\end{array}$ \\
\hline
\end{tabular}

\begin{tabular}{|c|c|}
\hline $\begin{array}{l}\text { Fogyasztói kap- } \\
\text { csolatok }\end{array}$ & $\begin{array}{l}\text { - hosszú távra szóló kapcsolatok } \\
\text { - személyes kapcsolatok } \\
\text { - online kapcsolattartási formák }\end{array}$ \\
\hline $\begin{array}{l}\text { Fogyasztói szeg- } \\
\text { mensek }\end{array}$ & $\begin{array}{l}\text { - háztartások } \\
\text { • mezőgazdasági termelők } \\
\text { • vállalatok } \\
\text { - állami szervezetek } \\
\text { • magán- és közbefektetők }\end{array}$ \\
\hline Csatornák & $\begin{array}{l}\text { - értékesítési képviselők } \\
\text { • konferenciák és események } \\
\text { • online és offline marketingeszközök } \\
\text { • aktív médiakapcsolatok } \\
\text { • vállalati weboldal }\end{array}$ \\
\hline Bevételi források & $\begin{array}{l}\text { • energiavásárlási szerződések } \\
\text { • lízingszerződések } \\
\text { • kormányzati támogatások } \\
\text { • állami és szövetségi ösztönzők } \\
\text { • helyi önkormányzatok és közmüvek által } \\
\text { folyósított támogatások } \\
\text { • adókedvezmények pl. beruházási adó- } \\
\text { kedvezmény, gyorsított értékcsökkenés } \\
\text { • megújulóenergia-tanúsítványok értékesí- } \\
\text { téséből származó bevételek } \\
\text { - fejlesztési, monitorozási és egyéb szol- } \\
\text { gáltatási díjak }\end{array}$ \\
\hline \multicolumn{2}{|c|}{ Infrastruktúra oldal } \\
\hline Kulcspartnerek & $\begin{array}{l}\text { - bankok, nagyvállalatok } \\
\text { • közmüszolgáltatók } \\
\text { - rendszerkomponensek gyártói és nagy- } \\
\text { kereskedői } \\
\text { - tanácsadó cégek } \\
\text { - ügyvédi irodák } \\
\text { - biztosítótársaságok } \\
\text { - telepítő és karbantartó cégek }\end{array}$ \\
\hline $\begin{array}{l}\text { Kulcstevékeny- } \\
\text { ségek }\end{array}$ & $\begin{array}{l}\text { • energiavásárlási szerződések kötése, } \\
\text { lízingmegoldások nyújtása } \\
\text { • alapkezelés } \\
\text { • kulcsrakészmegoldások nyújtása } \\
\text { • engedélyek beszerzése } \\
\text { • közmüszolgáltatókkal való kapcsolat- } \\
\text { tartás } \\
\text { • elérhető támogatásokhoz kapcsolódó } \\
\text { ügyintézés } \\
\text { • megújulóenergia-tanúsítványok értéke- } \\
\text { sítése } \\
\text { • rendszerteljesítmény-monitorozás } \\
\text { • karbantartás és szervízelés } \\
\text { • aktív marketingtevékenységek }\end{array}$ \\
\hline Kulcserőforrások & $\begin{array}{l}\text { • meglévő ügyfélbázis } \\
\text { • project management software } \\
\text { • jól képzett munkatársak }\end{array}$ \\
\hline Költségstruktúra & $\begin{array}{l}\text { - EVSZ és lízingkonstrukciók kezelése } \\
\text { (munkaerö- és IT-költségek) } \\
\text { - befektetök megszerzése } \\
\text { • értékesítési költségek } \\
\text { - marketingköltségek } \\
\text { • készletezési és raktározási költségek }\end{array}$ \\
\hline
\end{tabular}

Forrás: saját szerkesztés

\section{Közösség által megosztott üzleti modell}

Az elemzett kutatásokban e modell vonatkozásában is több elnevezés azonosítható, amelyek a következők: Shared solar (Feldman et al., 2015), Community solar (Asmus, 
2008; Huijben - Verbong, 2013; Konkle, 2013; Chwastyk - Sterling, 2015; Funkhouser et al., 2015; Deloitte, 2016; ICF Incorporated LLC, 2016), Community-shared (Augustine, 2015; Augustine - McGavisk, 2016; Zhang, 2016) és Community-owned model (Monica Oliphant Research, 2012). A továbbiakban a közösség által megosztott elnevezést használjuk.

Ebben a fejezetben célunk egy átfogó kép nyújtása a modellről, hozzájárulva a három koncepció közötti különbségek megértéséhez. A közösség által megosztott modell jelenleg fejlődésének korai szakaszában tart, amely megmutatkozik a kapcsolódó tanulmányok számában is. Ebből adódóan jelenleg még kevés információ áll rendelkezésre az üzleti modell egyes blokkjaira vonatkozóan.

Az Amerikai Egyesült Államokban 2006-ban indították el az első közösség által megosztott projekteket, annak érdekében, hogy a fogyasztók számára lehetővé tegyék a napelemparkokban megtermelt energia használatát, saját rendszer telepítése nélkül (Chwastyk - Sterling, 2015). Ebben a kategóriában az üzleti modellt müködtethetik többek között közmüvek, nonprofit szervezetek, napelemesprojekt-fejlesztők és számos egyéb szereplők (Feldman et al., 2015; Funkhouser et al., 2015; Augustine - McGavisk, 2016). A koncepció keretében a fogyasztók feliratkozhatnak a közösségi projektekre, illetve ezáltal lehetőségük nyílik napelempanelek tulajdonlására úgynevezett napelemparkokban vagy -kertekben. Ebből adódóan, a közösség tagjainak perspektívájából az üzleti modell egy költséghatékony alternatívát biztosít megújuló energiaforrások használatára, virtuális mérés alkalmazásán keresztül. Látható tehát, hogy az információs és kommunikációs technológiák fejlődése lehetővé teszi a közösség által megosztott modell elterjedését, és a működtető vállalaton belüli tudásmechanizmusok jelentős mértékben meghatározhatják a cég értékajánlatának megújítására, valamint a további szereplőkkel való kollaborációra irányuló képességét (Ferincz - Hortoványi, 2014; Hortoványi - Ferincz, 2015).

A közösség által megosztott modell vonzó lehetőséget kínál a közmüvek számára, mivel néhány nagyobb projekt segítségével könnyebben érhető el a méretgazdaságosság, mint számos kisméretű rendszer telepítésével (Feldman et al., 2015). A koncepció alkalmazásán keresztül a közmüveknek lehetőségük nyílik üzleti modelljük megújítására, valamint új értékesítési csatornák bevezetésére, amelyeken keresztül további szolgáltatásokat is eladhatnak (Deloitte, 2016). E tevékenységeken keresztül továbbá növelhetik fogyasztóik elköteleződését és elégedettségét (Augustine - McGavisk, 2016). A közösség által megosztott projektet létesíteni kívánó közmüszolgáltatóknak azonban nem szabad figyelmen kívül hagyniuk azt a tényezőt, hogy azon régiókban, ahol a villamos energia ára alacsonyabb, várhatóan alacsonyabb jövedelmezőséggel és hosszabb megtérülési idővel kell számolniuk. Ebből adódóan, a beruházási döntések meghozatala előtt részletes megtérülési számítások elkészítése válik szükségessé (Augustine, 2015). A modell áttekintése a 3. táblázatban látható.

\section{Fogyasztói oldal}

\section{Értékajánlat}

Számos lakossági fogyasztónak nem nyílik arra lehetősége, hogy saját ingatlanán létesítsen egy napelemes rendszert, amely három fő okra vezethető vissza. Ilyen ok lehet, hogy nem a fogyasztó az épület tulajdonosa (például albérlö), a fogyasztó társasházban él, vagy nem áll rendelkezésre kellő méretű hely a tetőszerkezeten egy rendszer telepítésére. Ezen okok mellett találkozhatunk olyan fogyasztókkal is, akik esztétikai megfontolásból nem akarnak saját ingatlanukon elhelyezni napelemet, vagy aggódnak a rendszer teljesítménye és hatékonysága miatt (Feldman et al., 2015; ICF Incorporated LLC, 2016). Az Amerikai Egyesült Államokban további tényezőket is azonosíthatunk, amelyek akadályt jelenthetnek egy saját rendszer vásárlása vagy lízingelése során. Ilyen akadály lehet, hogy bizonyos lakossági fogyasztók nem rendelkeznek hitelképes FICO pontszámmal (hitelképesség meghatározására szolgáló mutatószám, amely olyan tényezőket vesz figyelembe, mint például fizetési előzmények, eladósodás aktuális szintje stb.) és/vagy olyan államban élnek ahol nincsen érvényben az ún. „net metering” elszámolás. A GTM Research kutatásai alapján az amerikai háztartások mintegy $77 \%$-a nem tud ezen okok miatt saját napelemes rendszert telepíteni, ezáltal ök potenciális ügyfelek lehetnek a közösség által megosztott modellt alkalmazó vállalkozások számára (Honeyman, 2015).

Ezen akadályok és aggodalmak ellenére, a közösség által megosztott modell lehetőséget nyújt zöldenergia használatára a rendszer fizikai tulajdonlása nélkül, ezáltal hozzájárulva a villamosenergia-számla összegének csökkentéséhez, amely megvalósítására virtuális mérésen keresztül kerül sor (Center for Sustainable Energy, 2015). A modell keretében tehát a fogyasztók energiaszámláját korrigálják a megvásárolt energiatermelési részesedésükhöz igazítva (Augustine - McGavisk, 2016).

Emellett, a konstrukció segítségével finanszírozási akadályok (pl. magas kezdeti befektetési költség, pénzügyi erőforrások hiánya) is mérsékelhetők, mivel lehetőség nyílik a napelemes rendszerek csoportban történő megvásárlására, amely alacsonyabb költségeket eredményez, mint az egyénileg történő beruházás (Zhang, 2016). Mindent egybevetve, a konstrukció egy vonzó, hosszú távú megtakarítási lehetőséget ajánl alacsony kockázat mellett, rendszerint 5-20 évre szóló feliratkozási szerződések keretében. A kiszámíthatóság mellett a flexibilitás szintén lényegi eleme az értékajánlatnak. Amennyiben a fogyasztó eladni kívánja ingatlanát, úgy két lehetőség közül választhat. Először is értékesítheti feliratkozási szerződését az ingatlannal együtt vagy külön (Monica Oliphant Research, 2012). Abban az esetben, ha a fogyasztó nem szeretné eladásra kínálni napenergia-kötvényét és az adott szolgáltatási területen belül költözik, lehetőség nyílik arra, hogy magával vigye a korábban megkötött szerződését (Coughlin et al., 2012). A bemutatott elönyök mellett az üzleti modell továbbá hozzájárul a fogyasztók elköteleződésének növeléséhez a megújuló energiaforrások irányába. 


\section{Fogyasztói kapcsolatok}

A fogyasztó és a harmadik fél által tulajdonolt modellekhez hasonlóan, a fogyasztói kapcsolatok kialakítása és fenntartása szintén elengedhetetlen a modell sikeres müködtetése érdekében. Mivel a vállalatok hosszú távra szóló előfizetői szerződéseket kötnek fogyasztóikkal (legfeljebb 20 év), ezért a bizalom kialakítása érdekében többféle módon szükséges öket megközelíteni. Ilyen bizalom- és elkötelezettségépítési módként szolgálhat a különféle fogyasztói kiállításokon, közösségi eseményeken és találkozókon való részvétel, valamint az online csatornák alkalmazása (Huijben - Verbong, 2013; Konkle, 2013). A koncepció újdonsága révén, a modellhez kapcsolódó kutatások száma is alacsonynak mondható, de feltételezhető, hogy a személyes kapcsolati formák alkalmazása során e modell esetében is megjelennek az értékesítési munkatársak.

\section{Fogyasztói szegmensek}

Az adott ország szabályozási kereteitől függően, számos fogyasztói csoport azonosítható a szegmensek között. Fő ügyfélcsoportként azon lakossági fogyasztók definiálhatók, akik szembesülnek az értékajánlat részben bemutatott akadályokkal (pl. ingatlanbérlők). A lakossági fogyasztók mellett, vállalatok, valamint nonprofit szervezetek, például egyházak szintén megtalálhatók a megcélzott csoportok között (Asmus, 2008; Monica Oliphant Research, 2012; Zhang, 2016).

\section{Csatornák}

A közösség által megosztott modell az előző két modellhez viszonyítva még egy korai fejlődési szakaszban tart, melyből adódóan a folyamatos tanulás és információmegosztás kiemelt szerepet játszik a koncepció minél szélesebb körben történő megismertetése érdekében. Ebböl a célból a napelemparkok üzemeltetői gyakran rendeznek konferenciákat, találkozókat, oktatási programokat, kerti partikat és egyéb közösségi eseményeket. Emellett szintén megjelenik a vállalati weboldalak alkalmazása annak érdekében, hogy az információkat megosszák mind a potenciális fogyasztók, mind pedig a befektetők között (Huijben - Verbong, 2013; Konkle, 2013). Végül pedig kiemelendő az értékesítő munkatársak szerepe, akik jelentősen hozzájárulhatnak a hálózat bővítéséhez és a vállalat sikeréhez (Konkle, 2013).

\section{Bevételi források}

A közösség által tulajdonolt modell alapvetően két fö bevételi forrást biztosít a vállalatok számára. Egyik forrásként azonosítható az ún. napenergia-kötvények/részvények értékesítéséből származó bevétel, amellyel a fogyasztók megvásárolhatják a parkokban elöállított energia egy részét (Monica Oliphant Research, 2012). A kötvények árát a vállalatok a kormány által meghatározott adókulcsokhoz igazítják (Huijben - Verbong, 2013). Emellett bizonyos esetekben az ügyfelek egy kezdeti nagyobb összegü kifizetést folyósítanak a napelemparkok üzemeltetői számára, a projekt költségeinek fedezése érdekében. Egyes projekteknél a két fizetési lehetőség kombinációját alkalmazzák (Chwastyk - Sterling, 2015).
Ezeken felül, a szabályozási keretektől függően, a napelemparkok üzemeltetői rendszerint részesülhetnek szövetségi adókedvezményekből (USA) és állami ösztönzőkből, amelyek teljes körü felhasználása érdekében meghatározott számú közösségi előfizetővel kell rendelkezniük (Coughlin et al., 2012). A szövetségi adókedvezmények azonban csak egyéni tulajdonban álló lakóingatlanok vagy kereskedelmi tulajdonban lévő projektek esetén érhetők el. A közösség által tulajdonolt rendszerek egyik kategóriába sem illenek bele, amely jelentős kihívásokat generál a projektek tervezése során (Coughlin et al., 2012). Augustine (2015) a modell jellemzőinek vizsgálata során szintén kiemelte, hogy az USA bizonyos államaiban nem minden önkormányzat és közműszolgáltató esik adófizetési kötelezettség alá. Ebből adódóan, amennyiben egy közmüszolgáltató szeretne részesülni az elérhető adókedvezményekből magukban foglalva a megújuló energia beruházási jóváírást és a gyorsított értékcsökkenést - akkor szükséges szerződést kötnie egy olyan harmadik féllel, aki jogosult azok igénybevételére (Augustine, 2015).

\section{Infrastruktúra oldal}

\section{Kulcspartnerek}

A napelemprojektek üzemeltetőinek szoros partneri kapcsolatot kell kialakítaniuk a helyi energiaközmüvekkel, amely két okra vezethető vissza. Az előfizetők esetében fontos, hogy azon közmüszolgáltató ügyfelei legyenek, amely az adott projektet üzemeltető vállalat szolgáltatási területén belül található. Emellett a virtuális mérés során mért termelési és fogyasztási adatokat szinkronizálni szükséges a közművek számlázási rendszereivel, amely alapján korrigálhatják a fogyasztó által fizetendő végöszszeget (Coughlin et al., 2012). Amennyiben a projekt üzemeltetője felelős az infrastrukturális háttér kialakításáért is, akkor a kulcspartnerek között találhatunk továbbá gyártókat, nagykereskedőket, valamint kivitelező vállalatokat (Konkle, 2013).

\section{Kulcstevékenységek}

A napelemfarmok és -kertek tulajdonosai különböző feliratkozási lehetőségeket (pl. panelek vásárlása vagy lízingelése, adott energiamennyiség vagy kapacitás megvásárlása) kínálnak a fogyasztók számára, melyböl adódóan egyik fö tevékenységükként az előfizeti szerzödések kezelése azonosítható (Augustine, 2015; Augustine - McGavisk, 2016; Zhang, 2016). Ez a tevékenység magában foglalja a feliratkozói szerződések megkötését és a fogyasztókkal való kapcsolattartást. Szintén a feladatok közé tartozik a fogyasztóvédelem, az adatszolgáltatás és a kapcsolódó jogszabályoknak való megfelelés biztosítása (Chan et al., 2017). A szükséges infrastruktúrát rendszerint a napelemparkok tulajdonosai építik ki, de találkozhatunk olyan esetekkel is, ahol a befektetö már egy kész napelemparkot vásárol. A közösség által megosztott modell további üzemeltetési és karbantartási felelősséget ró a projekt üzemeltetőjére (Monica Oliphant Research, 2012). 


\section{Kulcserőforrások}

A harmadik fél által tulajdonolt modellhez hasonlóan, e koncepció esetében is kiemelt szerepet játszik a meglévő ügyfélbázis mint kulcserőforrás, mivel lehetővé teszi a vállalatok ismertségének növelését és a hálózat bővítését. Ezen túlmenöen, mivel a modell müködtetéséhez komplex projektmenedzsment-feladatok társulnak, és a termelési, valamint ügyfél adatokat szinkronizálni szükséges a közmüszolgáltatók rendszereivel, a vállalatoknak megfelelő IT-infrastruktúrával kell rendelkezniük (Coughlin et al., 2012). Ide sorolandó az olyan szoftvermegoldások kialakítása, amelyek támogatást nyújtanak mind az értékesítésben, projektmenedzsmentben, mind pedig a rendszerteljesítmény monitorozásában (Augustine, 2015). Szintén kulcserőforrásként jelennek meg a vállalat munkatársai, kiemelve az értékesítési képviselőket, akik jelentős mértékben hozzájárulnak a hálózat bővítéséhez és támogatást nyújtanak a modellből eredő komplexitás kezeléséhez (Konkle, 2013).

\section{Költségstruktúra}

Az elemzett kutatásokban nem részletezték a modellhez kapcsolódó költségeket, azonban a másik két koncepcióhoz hasonlóan, számos költségelemre következtethetünk.

Elöször is, amennyiben a kezdeti telepítési költségeket nem a közösség finanszírozza, akkor a szükséges infrastruktúra kialakítása jelentős pénzügyi terheket ró a projekt üzemeltetőjére. E probléma kiküszöbölése érdekében, számos olyan esettel találkozhatunk, ahol a jövőbeli feliratkozók által finanszírozzák a kezdeti költségeket. Ilyen példaként szolgálhat a Briston Energy Solar (BES) vállalat projektje, ahol különböző értékü kötvények (250 és 20000 font között) értékesítésével nyílt lehetőség a szükséges pénzügyi háttér megteremtésére. A BES kezdeményezése annyira sikeresnek bizonyult, hogy a beruházáshoz szükséges összeget három hét alatt összegyüjtötték, 103 lakossági fogyasztó által (Monica Oliphant Research, 2012). A kezdeti beruházási költségek mellett a költségstruktúra elemeinek jelentős része feltehetően a napelemes rendszerek müködtetéséhez és karbantartásához köthető. Feltételezhető továbbá, hogy a projektek és az előfizetők kezeléséhez - mivel ez a vállalat főtevékenysége - jelentős mértékü munkaerő- és informatikai költségek társulnak. Az informatikai költségek azonban nem csak elsősorban a projektmenedzsment feladatokhoz köthetők. A napelempark üzemeltetőjének komplex szoftvermegoldással kell rendelkeznie annak érdekében, hogy a termelési adatokat szinkronizálni tudja az energiaszolgáltatók számlázási rendszerével.

\section{3. táblázat}

Business Model Canvas: közösség által megosztott üzleti modell

\begin{tabular}{|l|l|}
\hline \multicolumn{1}{|l|}{ Fogyasztói oldal } \\
\hline \multirow{4}{*}{ Értékajánlat } & $\begin{array}{l}\text { • zöldenergia használata napelemes rend- } \\
\text { szer tulajdonlása nélkül } \\
\text { • csökkentett energiaszámla } \\
\text { • pénzügyi akadályok és költségek csök- } \\
\text { kentése } \\
\text { - rugalmasság }\end{array}$ \\
\hline
\end{tabular}

\begin{tabular}{|c|c|}
\hline $\begin{array}{l}\text { Fogyasztói } \\
\text { kapcsolatok }\end{array}$ & $\begin{array}{l}\text { - személyes kapcsolatok } \\
\text { - online kapcsolati formák }\end{array}$ \\
\hline $\begin{array}{l}\text { Fogyasztói } \\
\text { szegmensek }\end{array}$ & $\begin{array}{l}\text { - lakossági fogyasztók } \\
\text { - vállalatok } \\
\text { - nonprofit szervezetek } \\
\text { - intézményi fogyasztók (pl. önkormány- } \\
\text { zatok, egyetemek, rendvédelmi szervek) }\end{array}$ \\
\hline Csatornák & $\begin{array}{l}\text { - konferenciák, találkozók } \\
\text { - oktatási programok } \\
\text { - kerti partik, közösségi események } \\
\text { - weboldalak } \\
\text { - értékesítési képviselők }\end{array}$ \\
\hline Bevételi források & $\begin{array}{l}\text { • kötvények/részvények értékesítése } \\
\text { • elölegfizetések } \\
\text { • állami ösztönzők } \\
\text { • adókedvezmények pl. beruházási adó- } \\
\text { kedvezmény, gyorsított értékcsökkenés }\end{array}$ \\
\hline \multicolumn{2}{|c|}{ Infrastruktúra oldal } \\
\hline Kulcspartnerek & $\begin{array}{l}\text { • közmüszolgáltatók } \\
\text { • alvállalkozók (pl. kivitelező vállalatok) } \\
\text { • gyártók és nagykereskedők }\end{array}$ \\
\hline $\begin{array}{l}\text { Kulcstevékeny- } \\
\text { ségek }\end{array}$ & $\begin{array}{l}\text { - elöfizetői szerződések kezelése } \\
\text { - programmenedzsment: fogyasztóvéde- } \\
\text { lem, adatszolgáltatás, jogszabályoknak } \\
\text { való megfelelés biztosítása } \\
\text { - rendszertelepítés } \\
\text { - rendszerek vásárlása } \\
\text { - rendszerüzemeltetés és karbantartás }\end{array}$ \\
\hline Kulcserőforrások & $\begin{array}{l}\text { - meglévő ügyfélbázis } \\
\text { - IT-infrastruktúra } \\
\text { - alkalmazottak (pl. értékesítési képvi- } \\
\text { selők) }\end{array}$ \\
\hline Költségstruktúra & $\begin{array}{l}\text { - infrastruktúra kiépítése } \\
\text { - rendszerüzemeltetés és karbantartás } \\
\text { - munkaerö- és IT-költségek }\end{array}$ \\
\hline
\end{tabular}

Forrás: saját szerkesztés

\section{Összefoglalás és következtetések}

Napjainkban a fogyasztói tudatosság növekedésével egyre erösebb nyomás helyeződik a vállalatokra, hogy értékajánlatuk kialakításakor abba környezeti tényezőket is beépítsenek. Ezzel összhangban egyre nagyobb igény mutatkozik a lakossági fogyasztók irányából a megújuló energiaforrások használatára. Cikkünkben szakirodalmi áttekintés segítségével bemutattuk az alapvető napelemes üzleti modelleket a Business Model Canvas keretrendszer mentén. A szakirodalmi áttekintés alapján hat főszempont határozható meg, amelyek mentén az azonosított modellek jól elhatárolhatóvá válnak egymástól: üzleti modell fókusz, tulajdonos, rendszer üzemelésének helye, fizetési kötelezettség, finanszírozási időszak és karbantartási felelősség. Szintén fontos megjegyezni, hogy míg az első két modell esetében az üzleti modellt müködtető vállalat felé, addig a közösség által megosztott modellnél - az áramszámla korrekció eredményeként - az energiaszolgáltató felé is keletkezik fizetési kötelezettség. A modellek e szempontok mentén történő ismertetése a 4. táblázatban látható. 
Nemzetközi szinten azonosítható napelemes üzleti modellek

\begin{tabular}{|c|c|c|c|}
\hline & $\begin{array}{c}\text { Felhasználó } \\
\text { által tulajdo- } \\
\text { nolt modell }\end{array}$ & $\begin{array}{c}\text { Harmadik fél } \\
\text { által tulajdo- } \\
\text { nolt modell } \\
\end{array}$ & \begin{tabular}{|c|} 
Közösség \\
által megosz- \\
tott modell \\
\end{tabular} \\
\hline $\begin{array}{l}\text { Üzletimodell- } \\
\text { fókusz }\end{array}$ & $\begin{array}{l}\text { kulcsrakész } \\
\text { napelemes } \\
\text { rendszerek }\end{array}$ & $\begin{array}{l}\text { energiavásár- } \\
\text { lási, illetve } \\
\text { lízingszerző- } \\
\text { dések } \\
\end{array}$ & $\begin{array}{l}\text { feliratkozási } \\
\text { opciók }\end{array}$ \\
\hline Tulajdonos & fogyasztó & $\begin{array}{c}\text { napelemes cég } \\
\text { / befektető }\end{array}$ & $\begin{array}{c}\text { napelemes cég } \\
\text { / befektető }\end{array}$ \\
\hline $\begin{array}{c}\text { Rendszer } \\
\text { üzemelésének } \\
\text { helye }\end{array}$ & $\begin{array}{l}\text { fogyasztó } \\
\text { ingatlana }\end{array}$ & $\begin{array}{l}\text { fogyasztó } \\
\text { ingatlana }\end{array}$ & napelempark \\
\hline $\begin{array}{c}\text { Fizetési köte- } \\
\text { lezettség }\end{array}$ & $\begin{array}{c}\text { rendszer } \\
\text { megvásárlása } \\
\text { egészben vagy } \\
\text { részben (pl. } \\
\text { hitel) }\end{array}$ & $\begin{array}{l}\text { folyamatos } \\
\text { pénzáram: } \\
\text { megtermelt } \\
\text { energiameny- } \\
\text { nyiség / esz- } \\
\text { közlízing }\end{array}$ & $\begin{array}{l}\text { folyamatos } \\
\text { pénzáram: } \\
\text { eszközlízing } \\
\text { / megtermelt } \\
\text { és felhasznált } \\
\text { energia- } \\
\text { mennyiség } \\
\text { alapján, havi } \\
\text { áramszám- } \\
\text { la-korrekció } \\
\end{array}$ \\
\hline $\begin{array}{l}\text { Finanszírozá- } \\
\text { si időszak }\end{array}$ & - & 10-25 év & 5-20 év \\
\hline $\begin{array}{l}\text { Karbantartá- } \\
\text { si felelősség }\end{array}$ & fogyasztó & $\begin{array}{c}\text { szolgáltató } \\
\text { cég / fogyasz- } \\
\text { tó }\end{array}$ & $\begin{array}{l}\text { szolgáltató } \\
\text { cég }\end{array}$ \\
\hline
\end{tabular}

Forrás: saját szerkesztés

A főbb jellemzők ismertetése mellett, Osterwalder és Pigneur (2010) üzletimodell-definíciójára utalva, összefoglaltuk mindhárom modell értékajánlatát, valamint az értékteremtésének, nyújtásának és megragadásának módját (5. táblázat). A csökkentett energiaszámla mindhárom modell esetében közös vonásként azonosítható az értékajánlatokban, azonban a megtakarítás mértéke jelentősen eltérhet az egyes modellek között. Annak meghatározása, hogy melyik esetében számolhatunk kedvezőbb megtérülést eredményező beruházással, nagymértékben függ a finanszírozási megoldástól és az elérhető támogatásoktól (elsősorban a felhasználó által és a harmadik fél által tulajdonolt modell közötti választás során).

Összességében azonban elmondható, hogy a közösség által megosztott modell számos előnnyel szolgálhat mind a fogyasztók, mind pedig a vállalatok számára. A konstrukció által lehetővé válik a pénzügyi akadályok leküzdése, a kialakuló közösségnek és a vállalatok edukációs aktivitásának köszönhetően pedig a fogyasztók egyre informáltabbá válhatnak a megújuló energiaforrásokkal kapcsolatban. Mindezek mellett legnagyobb előnyként a méretgazdaságosság emelhető ki, amely lehetővé teszi a vállalatok számára, hogy a legújabb technológiai megoldásokat alkalmazzák, valamint a területi adottságok figyelembevételével kijelölhessék a napelempark létesítésére szolgáló legoptimálisabb területet, a lehető legnagyobb hatékonyság és termelési adatok elérése érdekében (területi előnyök kiaknázása).
A helyi és regionális körülményeknek megfelelö finanszírozási mechanizmusok és innovatív üzleti modellek jelentősen növelhetik a megújuló energiaforrások használatát. Emellett a közösség által tulajdonolt modell a közmüvek számára is jó lehetőséget nyújt üzleti modelljük megújítására, valamint versenyképességük növelésére. A közösségi projektek megvalósítása során azonban a közmüveknek számos tényezőt figyelembe kell venniük. A sikeres kivitelezéshez felül kell vizsgálni stratégiai eszközeiket, kulcskompetenciáikat, valamint partneri kapcsolataikat (Wüstenhagen - Wuebker, 2011). A nagy múltú energiaközmüveknek továbbá szükséges megtalálniuk az egyensúlyt a hagyományos és az új technológiák, valamint szolgáltatások fejlesztésére irányuló erőfeszítések között (Zavarkó et al., 2017). A fenntartható versenyelőny elérése érdekében szintén koncentrálniuk kell mind produktivitásuk, mind pedig abszorpciós kapacitásuk fejlesztésére (Hortoványi, 2016). Az Amerikai Egyesült Államokban érvényben lévő szövetségi adókedvezmények igénybevétele érdekében a közműveknek bizalmi, hosszú távra szóló partneri kapcsolatokat kell kialakítaniuk olyan szervezetekkel, amelyek jogosultak az elérhető kedvezményekre.

5. táblázat

Az egyes modellek értékajánlata, valamint az értékteremtésének, nyújtásának és megragadásának módja

\begin{tabular}{|c|c|c|c|}
\hline Érték & $\begin{array}{c}\text { Felhasználó ál- } \\
\text { tal tulajdonolt } \\
\text { modell }\end{array}$ & $\begin{array}{c}\text { Harmadik fél } \\
\text { által tulajdonolt } \\
\text { modell }\end{array}$ & $\begin{array}{c}\text { Közösség által } \\
\text { megosztott mo- } \\
\text { dell }\end{array}$ \\
\hline \multirow[t]{3}{*}{ 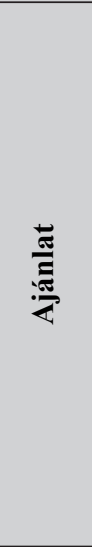 } & $\begin{array}{l}\text { kulcsrakész meg- } \\
\text { oldások } \\
\text { energiaközmüvek- } \\
\text { től való függet- } \\
\text { lenség, } \\
\text { kötelező betáplá- } \\
\text { lási tarifa rendszer } \\
\text { (Feed-in-tariff) } \\
\text { (negatív: magas } \\
\text { kezdeti telepítési } \\
\text { költség) }\end{array}$ & $\begin{array}{l}\text { alacsonyabb és } \\
\text { kiszámítható villa- } \\
\text { mosenergia-ár, } \\
\text { nincsen kezdeti } \\
\text { telepítési költség }\end{array}$ & $\begin{array}{c}\text { zöld energia hasz- } \\
\text { nálata napelemes } \\
\text { rendszer tulajdon- } \\
\text { lása nélkül } \\
\text { csökkentett pénz- } \\
\text { ügyi akadályok és } \\
\text { költségek, } \\
\text { rugalmasság }\end{array}$ \\
\hline & \multicolumn{3}{|c|}{ csökkentett energiaszámla } \\
\hline & & \multicolumn{2}{|c|}{$\begin{array}{l}\text { nincs üzemeltetési és karbantartási } \\
\text { kötelezettség }\end{array}$} \\
\hline \multirow[t]{2}{*}{ } & $\begin{array}{c}\text { karbantartás, } \\
\text { napelembiztosítás, } \\
\text { energetikai tanács- } \\
\text { adás }\end{array}$ & $\begin{array}{c}\text { energiavásárlási } \\
\text { és lízing szerződé- } \\
\text { sek, alapkezelés, } \\
\text { teljesítmény moni- } \\
\text { torozása, karban- } \\
\text { tartás és javítási } \\
\text { tevékenység }\end{array}$ & \begin{tabular}{|} 
előfizetői szerző- \\
dések kezelése, \\
program me- \\
nedzsment: fo- \\
gyasztóvédelem, \\
adatszolgáltatás, \\
jogszabályoknak \\
való megfelelés \\
biztosítása, \\
rendszertelepítés, \\
napelemes rend- \\
szerek vásárlása, \\
napelemes rend- \\
szerek müködteté- \\
se és karbantartása
\end{tabular} \\
\hline & \multicolumn{2}{|c|}{ napelemes rendszerek telepítése } & \\
\hline
\end{tabular}




\begin{tabular}{|c|c|c|c|}
\hline \multirow[t]{3}{*}{ 产 } & $\begin{array}{l}\text { napelemes séták, } \\
\text { többszintű mar- } \\
\text { keting, } \\
\text { szájreklám }\end{array}$ & $\begin{array}{l}\text { online és offline } \\
\text { marketingeszkö- } \\
\text { zök, } \\
\text { aktív médiakap- } \\
\text { csolatok }\end{array}$ & $\begin{array}{l}\text { oktatási progra- } \\
\text { mok, } \\
\text { kerti partik közös- } \\
\text { ségi események }\end{array}$ \\
\hline & \multicolumn{3}{|c|}{$\begin{array}{l}\text { értékesítő csapat, } \\
\text { weboldalak }\end{array}$} \\
\hline & & \multicolumn{2}{|c|}{ konferenciák, események, találkozók } \\
\hline 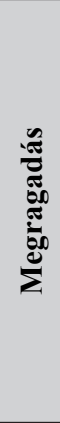 & $\begin{array}{l}\text { kulcsrakész meg- } \\
\text { oldások értékesíté- } \\
\text { se (különbözet) }\end{array}$ & $\begin{array}{c}\text { energiavásárlási és } \\
\text { lízingszerződések } \\
\text { dijjai (különbözet), } \\
\text { kormányzati támo- } \\
\text { gatások, állami és } \\
\text { szövetségi ösz- } \\
\text { tönzők, valamint } \\
\text { helyi önkormány- } \\
\text { zatok és közmüvek } \\
\text { által folyósított } \\
\text { támogatások }\end{array}$ & $\begin{array}{l}\text { napenergia-kötvé- } \\
\text { nyek értékesítése, } \\
\text { előlegfizetések } \\
\text { állami ösztönzök } \\
\text { adókedvezmények } \\
\text { pl. megújuló ener- } \\
\text { gia befektetési } \\
\text { adójóváírás és } \\
\text { gyorsított érték- } \\
\text { csökkenés }\end{array}$ \\
\hline
\end{tabular}

Forrás: saját szerkesztés

Kiemelendő továbbá, hogy a megújuló energiaforrások elterjedését nagymértékben akadályozhatják az egyes országokban érvényben lévő szabályozások, a szabályozási rendszerekben azonosítható hiányosságok, valamint szintén ilyen gátló tényezőként azonosítható a megfelelö támogatási programok hiánya (Pollmann - Podruzsik Fehér, 2014; Eleftheriadis - Anagnostopoulou, 2015; Engelken et al., 2016; Sen - Ganguly, 2016; Tongsopit et al., 2016; Potisat et al., 2017). A szabályozási akadályok leküzdésében az üzleti modellek csak korlátozottan tudnak segítséget nyújtani, ami a politikai döntéshozók számára egy olyan egységes szabályozási és ösztönzési rendszer kidolgozását irányozza elő, amely segítheti a megújulók elterjedését. Az egységes szabályozási rendszerek mellett hangsúlyozni szükséges, hogy az üvegházhatású gázok kibocsátásának csökkentésére irányuló fogyasztói politikai eszközök megfelelő kialakításával jelentős mértékü pozitív környezeti hatás realizálható, amennyiben azokkal sikerül elérni a társadalom szélesebb körét (Csutora - Zsóka, 2010, 2011).

Mindezek mellett, a közösség által megosztott modell továbbfejlődését várhatóan támogatni fogják az olyan trendek, mint például a digitális transzformáció és közösségi gazdaság (Heinrichs, 2013; Bleicher - Stanley, 2016). Az elemzett kutatások alapján összességében elmondható, hogy a közösség által megosztott modell számos területen generálhat előnyöket, több előnyt szolgáltatva, mint a másik két modell mind a fogyasztók, mind pedig a befektetök és vállalatok számára. A koncepció sikeres működtetése azonban az összetett technológiai infrastruktúra kiépítése mellett, felkészült, a modell komplexitását kezelni tudó vállalati menedzsmentet kíván meg.

\section{Felhasznált irodalom}

Ardani, K. - Margolis, R. (2010): Solar Technologies Market Report.

Asmus, P. (2008): Exploring New Models of Solar Energy Development. The Electricity Journal, 21(3), pp. 61-70.
Attia, B. - Parikh, M. (2016): Global Solar Demand Monitor Q4 2016.

Augustine, P. (2015): The Time Is Right for Utilities to Develop Community Shared Solar Programs. The Electricity Journal, 28(10), pp. 107-108.

Augustine, P. - McGavisk, E. (2016): The next big thing in renewable energy: Shared solar. Electricity Journal. Elsevier Inc., 29(4), pp. 36-42. doi: 10.1016/j. tej.2016.04.006.

Barakonyi, K. (2008): Üzleti modellek. Vezetéstudomány, 39(5), pp. 2-14.

Berger, Z. (2016): Third-Party Power Purchase Agreements and Solar Installations: How Non-Profits can Take Advantage of this Growing Industry.

Bleicher, J. - Stanley, H. (2016): Digitization as a catalyst for business model innovation a three-step approach to facilitating economic success. Journal of Business Management, (12), pp. 62-71.

Bolinger, M. A. (2009): Full Steam Ahead for PV in US homes?

Brocke, J. et al. (2009): Reconstructing the Giant: On the Importance of Rigour in Documenting the Literature Search Process. 17th European Conference on Information Systems, 9, pp. 2206-2217. doi: 10.1108/09600031211269721.

Brunekreeft, G. - Buchmann, M. - Meyer, R. (2016): The Rise of Third Parties and the Fall of Incumbents Driven by Large-Scale Integration of Renewable Energies: The Case of Germany. The Energy Journal, 37, pp. 243-262.

Cardenas, J. A. et al. (2014): A literature survey on Smart Grid distribution: An analytical approach. Journal of Cleaner Production, 65, pp. 202-216. doi: 10.1016/j. jclepro.2013.09.019.

Center for Sustainable Energy (2015): Virtual Net Metering Policy Background and Tariff Summary Report. Solar Market Pathways.

Chan, G. et al. (2017): Design choices and equity implications of community shared solar. The Electricity Journal

Chatterjee, S. (2013): Simple Rules for Designing Business Models. California Management Review, 55(2), pp. 97-124.

Chwastyk, D. - Sterling, J. (2015): Community Solar: Program Design Models.

Corfee, K. et al. (2014): California Solar Initiative: ThirdParty Ownership Market Impact Study. San Francisco

Coughlin, J. et al. (2012): A Guide to Community Shared Solar: Utility, Private, and Nonprofit Project Development. National Renewable Energy Laboratory, pp. 1-68.

Coughlin, J. - Cory, K. (2009): Solar Photovoltaic Financing: Residential Sector Deployment. Golden, Colorado

Couture, T. D. et al. (2010): A Policymaker's Guide to Feed-in Tariff Policy Design.

Csath, M. (2012): Üzletimodell-innováció. Budapest: Nemzeti Tankönyvkiadó

Csutora, M. - Zsóka, Á. (2010): Maximizing the Efficiency 
of Greenhouse Gas Related Consumer Policy. Journal of Consumer Policy, 34(1), pp. 67-90.

Csutora, M. - Zsóka, Á. (2011): Kevésből sokat, avagy az energiahatékonyságok programok eredményességének növelése. In: Sebezhetőség és adaptáció. A reziliencia esélyei. Budapest: MTA Szociológiai Intézet, pp. 133164.

Davidson, C. - Steinberg, D. (2013): Evaluating the impact of third-party price reporting and other drivers on residential photovoltaic price estimates. Energy Policy. Elsevier, 62, pp. 752-761. doi: 10.1016/j. enpol.2013.07.112.

Davidson, C. - Steinberg, D. - Margolis, R. (2015): Exploring the market for third-party-owned residential photovoltaic systems: insights from lease and powerpurchase agreement contract structures and costs in California. Environmental Research Letters. IOP Publishing, 10(2), pp. 1-12. doi: 10.1088/17489326/10/2/024006.

Deloitte (2016): Unlocking the value of community solar: Utilities find opportunity in the inevitable growth of distributed energy resources.

Dewald, U. - Truffer, B. (2011): Market Formation in Technological Innovation Systems-Diffusion of Photovoltaic Applications in Germany. Industry and Innovation, Routledge, 18(3), pp. 285-300. doi: 10.1080/13662716.2011.561028.

Drucker, P. F. (1954): The Practice of Management. New York: Harper and Row Publishers

Drury, E. et al. (2012): The transformation of southern California's residential photovoltaics market through third-party ownership. Energy Policy. Elsevier, 42, pp. 681-690. doi: 10.1016/j.enpol.2011.12.047.

Eleftheriadis, I. M. - Anagnostopoulou, E. G. (2015): Identifying barriers in the diffusion of renewable energy sources. Energy Policy. Elsevier, 80, pp. 153164. doi: 10.1016/j.enpol.2015.01.039.

Eley, C. (2016): Design Professional's Guide to Zero Net Energy Building. Island Press.

Engelken, M. et al. (2016): Comparing drivers, barriers, and opportunities of business models for renewable energies: A review', Renewable and Sustainable Energy Reviews. Elsevier, 60, pp. 795-809. doi: 10.1016/j.rser.2015.12.163.

Feldman, D. et al. (2015): Shared Solar: Current Landscape, Market Potential, and the Impact of Federal Securities Regulation. (April), p. 70.

Feldman, D. - Friedman, B. - Margolis, R. (2013): Financing, Overhead, and Profit: An In-Depth Discussion of Costs Associated with Third-Party Financing of Residential and Commercial Photovoltaic Systems. (October). Available at: www.nrel.gov/ publications.

Ferincz, A. - Hortoványi, L. (2014): Munkahelyi tanulást befolyásoló tényezők - humán-számítógép együttmüködés vizsgálata. Vezetéstudomány, 45(10), pp. $30-41$.

Frantzis, L. et al. (2008): Photovoltaics Business Models. Renewable Energy, (February).
Funkhouser, E. et al. (2015): Business model innovations for deploying distributed generation: The emerging landscape of community solar in the U.S.. Energy Research \& Social Science. Elsevier Ltd, 10, pp. 90-101. doi: 10.1016/j.erss.2015.07.004.

GTM Research (2015): U.S. Residential Solar Financing 2015-2020.

Hashim, H. - Ho, W. S. (2011): Renewable energy policies and initiatives for a sustainable energy future in Malaysia. Renewable and Sustainable Energy Reviews. Elsevier Ltd, 15(9), pp. 4780-4787. doi: 10.1016/j. rser.2011.07.073.

Heinrichs, H. (2013): Sharing Economy: A Potential New Pathway to Sustainability. GAIA, 22(4), pp. 228-231.

Hobbs, A. - Pierpont, B. (2013): Improving Solar Policy: Lessons from the solar leasing boom in California. (July). Available at: http://climatepolicyinitiative.org/ publication/improving-solar-policy-lessons-from-thesolar-leasing-boom-in-california/.

Honeyman, C. (2015): U.S. Community Solar Market Outlook 2015-2020.

Hortoványi, L. (2012): Entrepreneurial Management. Budapest: AULA Kiadó Kft.

Hortoványi, L. (2016): The Dynamic Nature of Competitive Advantage of the Firm. Advances in Economics and Business, 4(11), pp. 624-629.

Hortoványi, L. - Ferincz, A. (2015): The impact of ICT on learning on-the-job. The Learning Organization, 22(1), pp. 2-13. doi: 10.1108/TLO-06-2014-0032.

Horváth, D. - Móricz, P.-Szabó, Zs. R. (2018): Üzletimodellinnováció. Vezetéstudomány, 49(6), pp. 2-12. DOI https://doi.org/10.14267/VEZTUD.2018.06.01.

Huijben, J. C. C. M. - Verbong, G. P. J. (2013): Breakthrough without subsidies? PV business model experiments in the Netherlands. Energy Policy, 56(January 2012), pp. 362-370. doi: 10.1016/j.enpol.2012.12.073.

Hurlbut, D. J. - McLaren, J. - Gelman, R. (2013): Beyond Renewable Portfolio Standards: An Assessment of Regional Supply and Demand Conditions Affecting the Future of Renewable Energy in the West.

ICF Incorporated LLC (2016): Community Solar: An Opportunity to Enhance Sustainable Development on Landfills and Other Contaminated Sites.

Karakaya, E. - Nuur, C. - Hidalgo, A. (2016): Business model challenge: Lessons from a local solar company. Renewable Energy, Elsevier Ltd, 85, pp. 1026-1035. doi: 10.1016/j.renene.2015.07.069.

Kollins, K. (2008): Solar PV Financing: Potential Legal Challenges to the Third Party PPA Model. Nicholas School of the Environment of Duke University.

Kollins, K. - Speer, B. - Cory, K. (2010): Solar PV Project Financing: Regulatory and Legislative Challenges for Third-Party PPA', Contract, (February), pp. 1-43.

Konkle, D. (2013): A Guidebook for Community Solar Programs in Michigan Communities. Great Lakes Renewable Energy Association.

Maglio, P. P. - Spohrer, J. (2013): A Service Science Perspective on Business Model Innovation. Industrial Marketing Management, 42, pp. 665-670. 
Magretta, J. (2002): Why Business Models Matter. Harvard Business Review, 80(5), p. 86-92.

Mond, A. (2017): U.S. Residential Solar Finance Update: H2 2017.

Monica Oliphant Research (2012). CASE STUDIES Finding the Best Approach -Case Studies. pp. 1-16.

Móricz, $P$. (2007). Üzleti modellezés és az internetes üzleti modellek. Vezetéstudomány, 38(4), pp. 14-29.

Móricz, P. (2009): Élenjáró magyarországi internetes vállalkozásokfejlödése az üzleti modell nézőpontjából. Ph.D. értekezés. Budapesti Corvinus Egyetem.

Munasinghe, M. (1990): Energy Analysis and Policy: Selected Works. Butterworths

Nemzeti Fejlesztési Minisztérium (2016): Otthon Melege Program: Családi házak energia-megtakarítást eredményező korszerűsítésének, felújításának támogatása alprogram. Budapest

NREL (2009): Power Purchase Agreement Checklist for State and Local Governments. Colorado

Osterwalder, A. - Pigneur, Y. (2010): Business Model Generation, A Handbook for Visionaries, Game Changers, and Challengers. doi: 10.1523/ JNEUROSCI.0307-10.2010.

Overholm, H. (2015): Spreading the rooftop revolution: What policies enable solar-as-a-service? Energy Policy, Elsevier, 84, pp. 69-79. doi: 10.1016/j. enpol.2015.04.021.

Överholm, H. (2013): Alliance Initiation by Technologyintermediary Ventures in the US Solar Industry. University of Cambridge

Palvia, P. et al. (2004): Research Methodologies in MIS: An Update. Communications of the Association for Information Systems, 14(1), pp. 526-542. Available at: http://search.ebscohost.com/login.aspx?direct=true\&d $\mathrm{b}=$ buh\&AN $=16744222 \&$ site $=$ ehost-live.

Pateli, A. G. - Giaglis, G. M. (2005): Technology innovation-induced business model change: A contingency approach. Journal of Organisational Change Management, 18, pp. 167-183.

Pollmann, O. - Podruzsik, S. - Fehér, O. (2014): Social Acceptance of Renewable Energy: Some Examples from Europe and Developing Africa. Society and Economy, 36(2), p. 217-231.

Potisat, T. et al. (2017): To buy the system or to buy the service: the emergence of a solar service model in Thailand. Renewable Energy Focus, Elsevier Ltd, 21(October), pp. 1-10. doi: 10.1016/j.ref.2017.06.002.

REN21 (2016): Renewables 2016 Global Status Report. Available at: http://www.ren21.net/resources/ publications/.

Schoettl, J.-M. - Lehmann-Ortega, L. (2011): Photovoltaic business models: threat or opportunity for utilities? In: Wustenhagen, R. and Wuebker, R. (eds): Handbook of research on energy entrepreneurship. Cheltenham, United Kingdom: Edward Elgar. Available at: https://www.dawsonera.com/guard/protected/ dawson.jsp?name=https://idp.shibboleth.stir.ac.uk/ shibboleth\&amp.

Seel, J. - Barbose, G. L. - Wiser, R. H. (2014): An analysis of residential PV system price differences between the United States and Germany. Energy Policy, Elsevier, 69, pp. 216-226. doi: 10.1016/j.enpol.2014.02.022.

Sen, S. - Ganguly, S. (2016): Opportunities, barriers and issues with renewable energy development A discussion. Renewable and Sustainable Energy Reviews. Elsevier, (May), pp. 1-12. doi: 10.1016/j. rser.2016.09.137.

Sherwood, L. (2014): U.S. Solar Market Trends 2013.

Solangi, K. H. et al. (2011): A review on global solar energy policy. Renewable and Sustainable Energy Reviews, Elsevier Ltd, 15(4), pp. 2149-2163. doi: 10.1016/j.rser.2011.01.007.

Sommerfeldt, N. - Muyingo, H. - Klintberg, T. (2016): Photovoltaic Systems for Swedish Prosumers. A technical and economic analysis focused on cooperative multi-family housing.

Strupeit, L. - Palm, A. (2016): Overcoming barriers to renewable energy diffusion: Business models for customer-sited solar photovoltaics in Japan, Germany and the United States. Journal of Cleaner Production, Elsevier Ltd, 123, pp. 124-136. doi: 10.1016/j. jclepro.2015.06.120.

Thumann, A. - Woodroof, E. A. (2008) Energy Project Financing: Resources and Strategies for Success. The Fairmont Press, Inc.

Tongsopit, S. et al. (2016): Business models and financing options for a rapid scale-up of rooftop solar power systems in Thailand. Energy Policy, Elsevier, 95, pp. 447-457. doi: 10.1016/j.enpol.2016.01.023.

Trabish, H. K. (2015): California utilities ready plans for community solar programs. Utility Dive. Available at: http://www.utilitydive.com/news/ california-utilities-ready-plans-for-communitysolar-programs/394045/.

Webster, J. - Watson, R. T. (2002): Analyzing the Past to Prepare for the Future: Writing a Literature Review. MIS Quarterly, 26(2), pp. xiii-xxiii. doi: 10.1.1.104.6570.

Wirtz, B. W. - Schilke, O. - Ullrich, S. (2010). Strategic development of business models: Implications of the Web 2.0 for creating value on the Internet. Long Range Planning, 43, pp. 272-290.

Wüstenhagen, R. - Wuebker, R. (2011): Handbook of Research on Energy Entrepreneurship. Edward Elgar Publishing Limited.

Zavarkó, M. et al. (2017): Innovation and Knowledge Management in the Energy Sector. Journal of Energy Technologies and Policy, 7(1), p. 45-53.

Zhang, S. (2016): Innovative business models and financing mechanisms for distributed solar PV (DSPV) deployment in China. Energy Policy. Elsevier, 95, pp. 458-467. doi: 10.1016/j.enpol.2016.01.022. 